\title{
圧縮力が作用する冷間成形溝形断面部材の弾性局部座屈耐力と座屈挙動 BUCKLING STRENGTH AND BEHAVIOR OF ELASTIC LOCAL BUCKLING FOR COLD-FORMED CHANNEL MEMBER UNDER COMPRESSION
}

\author{
三 井 和 也*1, 五十嵐 規矩夫*2 \\ Kazuya MITSUI and Kikuo IKARASHI
}

\begin{abstract}
This study's purpose is to analyze channel members' local buckling behavior based on the energy method. A mechanical model and displacement functions that simulate the local buckling behavior were proposed. An evaluation formula for the local buckling that directly reflects the channel member's parameters was proposed via the proposed mechanical model. Based on this proposed formula, the relationship between the cross-sectional shape and the buckling strength is investigated. Also, an approximate formula is proposed. The reliability and the effectiveness of the proposed formula and the approximate formula are shown by comparing finite element analysis results.
\end{abstract}

Keywords: Thin-wall steel structures, Light weight steel, Channel member, Lipped channel member, Local buckling, Energy method 薄肉鋼板構造，軽量形鋼，溝形断面部材，リップ付溝形断面部材，局部座屈，エネルギー法

\section{1. 序}

冷間成形された溝形断面部材あるいはリップ付溝形断面部材（以 降，冷間成形された両部材を総称して溝形断面部材とする）に代表 される一軸対称開断面部材に圧縮力が作用した場合，曲げ座屈のよ うな全体座屈を除けば Fig. 1 に示す局部座屈とゆがみ座屈, あるい はこれら座屈性状が連成した局所系の座屈性状が部材に発現する ${ }^{11}$. 本論文では Fig. 1(a)のようにウェブとフランジの接合線，フランジ とリップの接合線が移動しない状態で変形する座屈性状を局部座屈 と, Fig. 1(b)のようにウェブとフランジの接合線が移動せず，フラン ジとリップの接合線が移動する座屈性状をゆがみ座屈と定義する ${ }^{11}$. 溝形断面部材の局所系の座屈耐力に関する研究は欧米や豪州といっ た海外を中心として精力的に行われ，溝形断面部材で発生する局部

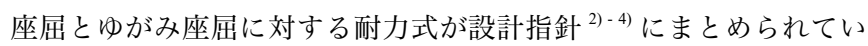
る。近年ではゆがみ座屈に関する研究が活発に行われ，Hancock ${ }^{5)-9)}$ や Schafer ${ }^{10)}$ - 13) の一連の研究がその代表例である。一方，局部座屈に 関する研究は多くない.これは単純支持や固定支持といった簡易な 境界条件の板要素で発生する局部座屈の座屈耐力が既知であるため, 部材を構成する各板要素の境界条件に応じて局部座屈耐力を算定し, 最も座屈耐力の低い板要素により部材耐力を決定する簡易な設計手

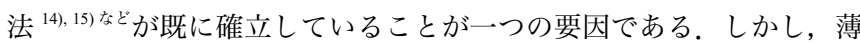
板軽量形鋼 ${ }^{16)}$ に代表される，部材を薄肉化し高度利用することを目 的とした部材に対し，このような簡易な耐力算定手法を適用した場 合，局部座屈耐力を精緻に算定することができず，部材の利点が喪 失される懸念がある。この問題を解決するべく, 隣接する板要素に よる拘束効果を適切に境界条件に反映させる研究が Schafer ${ }^{10)}$ や小橋
ら ${ }^{17)-19)}$ により行われている．特に小橋らは隣接する板要素による 拘束効果を考慮した耐力式を理論的に導出するとともに，工学的な 判断に基づいた簡易な弾性局部座屈耐力式を提案している。一方で, 溝形断面部材のウェブを例にとると, ウェブの境界条件は隣接する 板要素のフランジに加えリップにも影響されるため, 隣接する板要 素の拘束効果を考慮するだけでなく, 部材断面全体で拘束効果を考 慮する必要がある。また，溝形断面部材の断面形状に応じ変化する 局部座屈耐力と部材全体に生じる座屈性状に対する検討は十分では ない，本論文では弾性座屈耐力を扱うが，弾性解は最大耐力を推定 するための指標 2) -4), 15), 16)などとして使用されており，最大耐力を決定 する座屈性状とその弾性座屈耐力を求めることは重要と考える.

前述のように, 薄板部材の従来の座屈耐力算定方法は部材を構成 する各板要素の局部座屈耐力を算出し，その耐力を比較することで 部材耐力を算出していたが，本論文では部材を構成する各板要素間

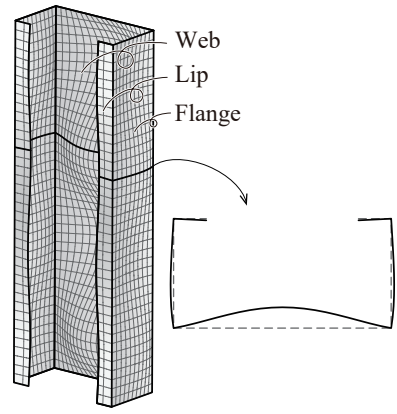

(a) Local buckling

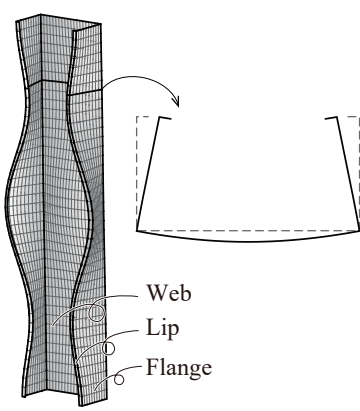

(b) Distortional buckling
Fig. 1 Buckling mode in channel member

*1 東京工業大学環境 ·社会理工学院建築学系 助教 - 博士 (工学)

*2 東京工業大学環境・社会理工学院建築学系 教授·博士 (工学)

Assist. Prof., Dept. of Arch. and Build. Eng., Tokyo Institute of Technology, Dr.Eng. Prof., Dept. of Arch. and Build. Eng., Tokyo Institute of Technology, Dr.Eng. 
の拘束効果を考慮した上で, 各板要素の局部座屈耐力を比較するこ となく部材としての局部座屈耐力を算出できる弾性局部座屈耐力式 の構築を目的とする，具体的には，隣接する板要素による拘束効果 のみならず，部材を構成する各板要素の相互作用による拘束効果を 考慮すべく, ウェブ・フランジ・リップの座屈波形を一連の変位関 数により表現し，エネルギー法に基づき溝形断面部材の弾性局部座 屈耐力式と簡易な近似式を導出する。 また，本論文で提案する弾性 局部座屈耐力式を用いた数值解析により，溝形断面部材の断面形状 と座屈性状の関係性を明らかにする。なお，本論文で対象とする溝 形断面部材の断面形状は Fig. 1 に示すように板厚が断面内で一定であ り，ウェブやフランジに中間リブが設けられていない，各板要素が 直交に接合された溝形断面部材である。冒頭で述べたように溝形断 面部材の局所系の座屈性状では, 局部座屈とゆがみ座屈, これら座 屈性状が連成した座屈性状が部材に発現するが，本論文では局部座 屈が単独で発現する場合のみを検討対象とし, 他の座屈性状や連成 座屈による影響は考慮しない.

\section{2. 圧縮力を受ける冷間成形溝形断面部材の弾性局部座屈耐力}

\section{1. 解析モデルおよび座屈変位関数}

Fig. 2 に本論文で用いる解析モデルを示す。本論文で使用する溝形 断面部材の断面形状や応力状態を表現する変数は Table 1 にまとめて 示している. 冷間成形部材を対象としているため, 解析モデルの板 厚は断面内で全て一定である，断面四隅の曲げ加工部あるいは溶接 部は無視するものとする，両部材端の断面は固定支持である．各板 要素の両材端縁は幅方向まわりの回転が許容されている．また，局 部座屈時の任意箇所の断面内における座屈変位はウェブとフランジ の接合線とフランジとリップの接合線が移動しない状態である。た だし，各板要素は接合線上において直交を保った状態である。これ ら変形条件を満足させるように変位関数を設定することで, ウェブ・ フランジ・リップの座屈波形を連続的に一連の変位関数で表現でき, 板要素間の相互作用を耐力式に反映することができる，以下ではウェ ブ・フランジ・リップの変位関数を設定する. ウェブの断面内変位 はフランジとウェブの接合線が移動せず，フランジにより支持辺を 補剛された状態であるため, ウェブの接合線は $x$ 軸周りの回転が弾 性支持された状態となる。したがって，ウェブの変位関数は以下の 関数により近似することができる.

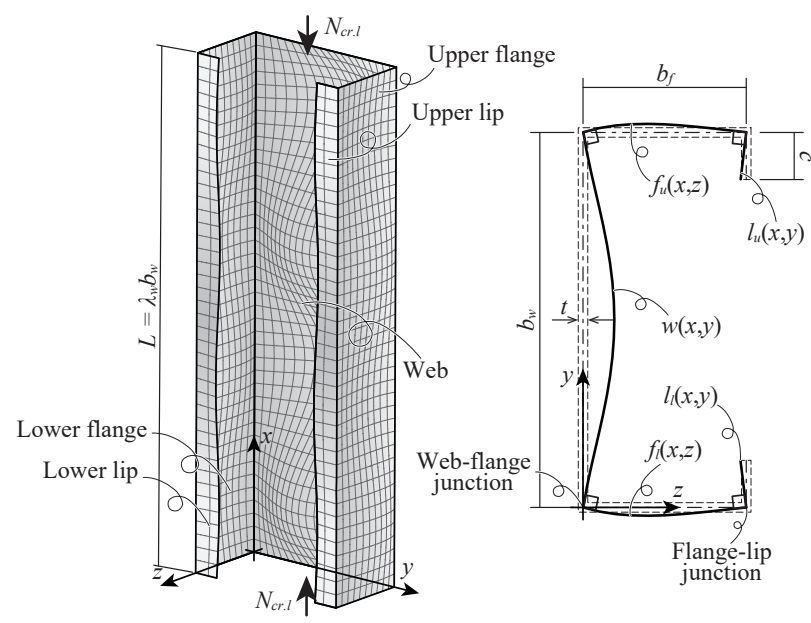

Fig. 2 Local bucklnig under pure compression and its deflection

$$
w(x, y)=\sin \frac{k \pi x}{L}\left[l_{a} \sin \frac{\pi y}{b_{w}}+l_{b}\left(1+\cos \pi\left(\frac{2 y}{b_{w}}-1\right)\right)\right]
$$

式(1) 中の $k$ は材長方向の半波長を 1 単位とする波数であり, $l_{a}, l_{b}$ は 未定係数である. 式(1) 中の括弧内第 1 項目は両端単純支持の座屈波 形を，第 2 項目は両端固定支持の座屈波形を表現できる関数であり， ウェブの断面内変位はこれら両関数の線形和として表現される ${ }^{20)}$. 両フランジの断面内に発生する局部座屈波長の頂点は, フランジ中 央からややウェブよりの位置に発生することが文献 1)の実験および 数值解析による観察において確認されたことから, 本論文では両フ ランジの変位関数を以下の関数により近似する.

$$
\begin{aligned}
& f_{u}(x, z)=\sin \frac{k \pi x}{L}\left(l_{c} \sin \frac{\pi z}{b_{f}}+l_{d} \sin \frac{\left(b_{f}-z\right)^{2} \pi}{b_{f}^{2}}\right) \\
& f_{l}(x, z)=-\sin \frac{k \pi x}{L}\left(l_{c} \sin \frac{\pi z}{b_{f}}+l_{d} \sin \frac{\left(b_{f}-z\right)^{2} \pi}{b_{f}^{2}}\right)
\end{aligned}
$$

$l_{c}, l_{d}$ は未定係数である. 式(2), 式 (3) 中の括弧内第 1 項目はフラン ジ中央に座屈波長の頂点を発生させる関数であり, 第 2 項目はウェ ブよりに座屈波長の頂点を発生させる関数である.ここで, ウェブ とフランジは直交を保持した状態で変形する。この変形条件は式 (4) のように表現できる.

$$
\left\{\begin{array}{l}
\left.\frac{\partial w(x, y)}{\partial y}\right|_{y=b_{w}}=\left.\frac{\partial f_{u}(x, z)}{\partial z}\right|_{z=0} \\
\left.\frac{\partial w(x, y)}{\partial y}\right|_{y=0}=\left.\frac{\partial f_{l}(x, z)}{\partial z}\right|_{z=0}
\end{array}\right.
$$

この条件式から, 未定係数 $l_{a}, l_{c}, l_{d}$ には以下の関係式が成立する.

$$
l_{a}=-\frac{b_{w}}{b_{f}}\left(l_{c}+2 l_{d}\right)
$$

リップはフランジに対して直交であるため, 両フランジに取り付く リップの変位関数は式 (6) および式 (7)のように表現できる.

$$
\begin{aligned}
& l_{u}(x, y)=\left.\frac{\partial f_{u}(x, z)}{\partial z}\right|_{z=b_{f}} \cdot y=\frac{\pi}{b_{f}} \sin \frac{k \pi x}{L} l_{c} \cdot y \\
& l_{l}(x, y)=\left.\frac{\partial f_{l}(x, z)}{\partial z}\right|_{z=b_{f}} \cdot y=-\frac{\pi}{b_{f}} \sin \frac{k \pi x}{L} l_{c} \cdot y
\end{aligned}
$$

以降ではエネルギー法により溝形断面部材の弾性局部座屈耐力を 求める。まず，設定した変位関数に基づきひずみエネルギー増分を 求めると式(8)のようになる。 $\Delta U_{1}, \Delta U_{2}, \Delta U_{3}$ はそれぞれウェブ，フラ ンジ, リップの各板要素 1 枚分のひずみエネルギー増分である. なお, 両フランジ，両リップの変形は対称であるため，ひずみエネルギー

Table 1 Parameters and symbols

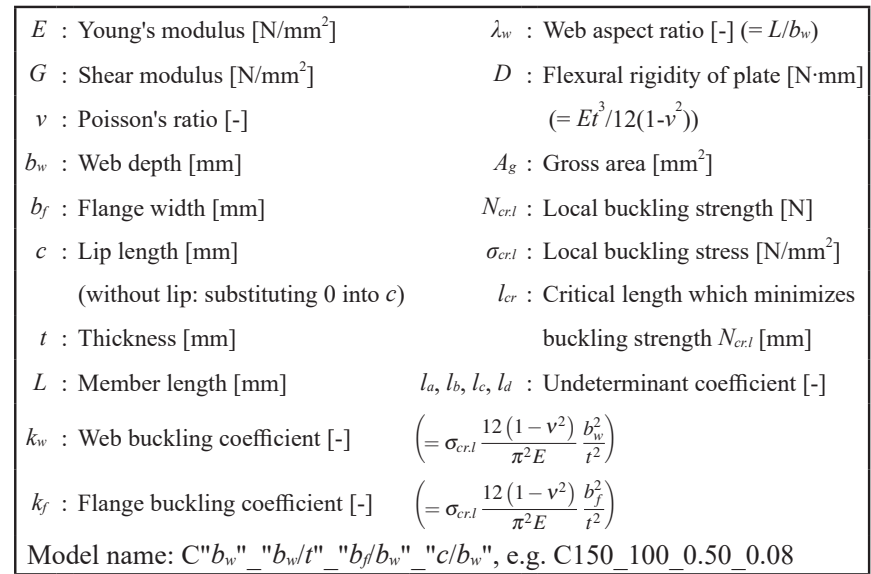


増分はそれぞれ同值となる。

$$
\begin{aligned}
& \Delta U_{1}=\frac{1}{2} D \int_{0}^{L} \int_{0}^{b_{w}} {\left[\left(\frac{\partial^{2} w}{\partial x^{2}}\right)^{2}+\left(\frac{\partial^{2} w}{\partial y^{2}}\right)^{2}\right.} \\
&\left.+2 v \frac{\partial^{2} w}{\partial x^{2}} \frac{\partial^{2} w}{\partial y^{2}}+2(1-v)\left(\frac{\partial^{2} w}{\partial x \partial y}\right)^{2}\right] \mathrm{dydx} \\
& \Delta U_{2}=\frac{1}{2} D \int_{0}^{L} \int_{0}^{b_{f}}\left[\left(\frac{\partial^{2} f_{u}}{\partial x^{2}}\right)^{2}+\left(\frac{\partial^{2} f_{u}}{\partial z^{2}}\right)^{2}\right. \\
&\left.+2 v \frac{\partial^{2} f_{u}}{\partial x^{2}} \frac{\partial^{2} f_{u}}{\partial z^{2}}+2(1-v)\left(\frac{\partial^{2} f_{u}}{\partial x \partial z}\right)^{2}\right] \mathrm{dzdx} \\
& \Delta U_{3}=\frac{1}{2} D \int_{0}^{L} \int_{0}^{c}\left[\left(\frac{\partial^{2} l_{u}}{\partial x^{2}}\right)^{2}+2(1-v)\left(\frac{\partial^{2} l_{u}}{\partial x \partial y}\right)^{2}\right] \mathrm{dydx}
\end{aligned}
$$

溝形断面部材に圧縮力が作用し, 部材断面に一様な圧縮応力が作用 すると仮定すると，外力がウェブ，フランジ，リップの 1 枚あたり の各板要素になす仕事増分 $\Delta T_{1}, \Delta T_{2}, \Delta T_{3}$ はそれぞれ式(9.a)から式(9.c) のようになる。

$$
\begin{aligned}
& \Delta T_{1}=\frac{1}{2} \sigma_{c r . l} t \int_{0}^{L} \int_{0}^{b_{w}}\left(\frac{\partial w}{\partial x}\right)^{2} \mathrm{dydx} \\
& \Delta T_{2}=\frac{1}{2} \sigma_{c r . l} t \int_{0}^{L} \int_{0}^{b_{f}}\left(\frac{\partial f_{u}}{\partial x}\right)^{2} \mathrm{dzdx} \\
& \Delta T_{3}=\frac{1}{2} \sigma_{c r . l} t \int_{0}^{L} \int_{0}^{c}\left(\frac{\partial l_{u}}{\partial x}\right)^{2} \mathrm{dydx}
\end{aligned}
$$

式 (5), 式 (8) および式 (9)より，ひずみエネルギー増分の総和と外力 のなす仕事増分の総和が等しいとおき, 助変数 $l_{b}, l_{c}, l_{d}$ で偏微分する と座屈条件式 (10) を得る.

$$
\left\{\begin{array}{ccc}
m_{1}-m_{2} \sigma_{c r . l} & m_{3}-m_{4} \sigma_{c r . l} & m_{5}-m_{6} \sigma_{c r . l} \\
m_{3}-m_{4} \sigma_{c r l} & m_{7}-m_{8} \sigma_{c r l} & m_{9}-m_{10} \sigma_{c r . l} \\
m_{5}-m_{6} \sigma_{c r . l} & m_{9}-m_{10} \sigma_{c r . l} & m_{11}-m_{12} \sigma_{c r . l}
\end{array}\right\}\left\{\begin{array}{l}
l_{b} \\
l_{c} \\
l_{d}
\end{array}\right\}=0
$$

式(10)が自明な解以外を持つ, すなわち式 (10) 左辺の行列式がゼロ となる正の最小実数解の応力度を求めることで, 弾性局部座屈耐力 $\sigma_{c r l}$ を求めることができる.

$$
\begin{aligned}
& \sigma_{c r l}(k)=r^{1 / 3}\left[\cos \left(\frac{\theta_{u}}{3}+\frac{2 \pi}{3}\right)+\cos \left(\frac{\theta_{u}}{3}-\frac{4 \pi}{3}\right)\right]-\frac{C_{2}}{3} \\
& r=\sqrt{(q / 2)^{2}+\left|(q / 2)^{2}+(p / 3)^{3}\right|} \\
& \theta_{u}=\cos ^{-1}(-q / 2 r) \\
& p=C_{1}-C_{2}^{2} / 3 \\
& q=C_{0}-C_{1} C_{2} / 3+2 C_{2}^{3} / 27 \\
& C_{n}=c_{n} / c_{3} \quad(n=0,1,2) \\
& c_{3}=-\left|\begin{array}{ccc}
m_{2} & m_{4} & m_{6} \\
m_{4} & m_{8} & m_{10} \\
m_{6} & m_{10} & m_{12}
\end{array}\right| \\
& c_{2}=\left|\begin{array}{ccc}
m_{1} & -m_{4} & -m_{6} \\
m_{3} & -m_{8} & -m_{10} \\
m_{5} & -m_{10} & -m_{12}
\end{array}\right|+\left|\begin{array}{ccc}
-m_{2} & m_{3} & -m_{6} \\
-m_{4} & m_{7} & -m_{10} \\
-m_{6} & m_{9} & -m_{12}
\end{array}\right|+\left|\begin{array}{ccc}
-m_{2} & -m_{4} & m_{5} \\
-m_{4} & -m_{8} & m_{9} \\
-m_{6} & -m_{10} & m_{11}
\end{array}\right| \\
& c_{1}=\left|\begin{array}{ccc}
m_{1} & m_{3} & -m_{6} \\
m_{3} & m_{7} & -m_{10} \\
m_{5} & m_{9} & -m_{12}
\end{array}\right|+\left|\begin{array}{ccc}
-m_{2} & m_{3} & m_{5} \\
-m_{4} & m_{7} & m_{9} \\
-m_{6} & m_{9} & m_{11}
\end{array}\right|+\left|\begin{array}{ccc}
m_{1} & -m_{4} & m_{5} \\
m_{3} & -m_{8} & m_{9} \\
m_{5} & -m_{10} & m_{11}
\end{array}\right| \\
& c_{0}=\left|\begin{array}{ccc}
m_{1} & m_{3} & m_{5} \\
m_{3} & m_{7} & m_{9} \\
m_{5} & m_{9} & m_{11}
\end{array}\right|
\end{aligned}
$$

式(17) に含まれる $m_{1}, m_{2}, \cdots, m_{12}$ は式 (8) および式 (9) を積分計算する
ことで以下のように求めることができる。積分項が無理数となる場 合は有効数字 5 桁までの小数により表記している.

$$
\begin{aligned}
& m_{1}=\frac{\pi D}{4 b_{w}^{2}}\left[3\left(\frac{k}{\lambda_{w}}\right)^{2}+8+16\left(\frac{\lambda_{w}}{k}\right)^{2}\right] \\
& m_{2}=\frac{3 t}{4} \\
& m_{3}=-\frac{4 \pi D}{3 b_{w} b_{f}}\left(\frac{k}{\lambda_{w}}+\frac{\lambda_{w}}{k}\right)^{2} \\
& m_{4}=-\frac{4 t b_{w}}{3 \pi b_{f}} \\
& m_{5}=-\frac{8 \pi D}{3 b_{w} b_{f}}\left(\frac{k}{\lambda_{w}}+\frac{\lambda_{w}}{k}\right)^{2} \\
& m_{6}=-\frac{8 t b_{w}}{3 \pi b_{f}} \\
& m_{7}=\frac{\pi^{2} D}{4 b_{w} b_{f}}\left\{\frac{b_{w}}{b_{f}}\left(\frac{k}{\lambda_{w}}+\frac{\lambda_{w}}{k}\right)^{2}+2\left(\frac{k b_{f}}{\lambda_{w} b_{w}}+\frac{\lambda_{w} b_{w}}{k b_{f}}\right)^{2}\right. \\
& \left.+\frac{4 c}{3 b_{f}}\left[\left(\frac{k \pi c}{\lambda_{w} b_{w}}\right)^{2}+6(1-v)\right]\right\} \\
& m_{8}=\frac{t b_{w}^{2}}{12 b_{f}^{2}}\left[3+6\left(\frac{b_{f}}{b_{w}}\right)^{3}+4 \pi^{2}\left(\frac{c}{b_{w}}\right)^{3}\right] \\
& m_{9}=\frac{\pi^{2} D}{2 b_{w} b_{f}}\left[\frac{b_{w}}{b_{f}}\left(\frac{k}{\lambda_{w}}+\frac{\lambda_{w}}{k}\right)^{2}+0.76981\left(\frac{k b_{f}}{\lambda_{w} b_{w}}+\frac{\lambda_{w} b_{w}}{k b_{f}}\right)^{2}\right] \\
& m_{10}=\frac{t b_{f}}{2 b_{w}}\left[\left(\frac{b_{w}}{b_{f}}\right)^{3}+0.76981\right] \\
& m_{11}=\frac{\pi^{2} D}{2 b_{w} b_{f}}\left\{2 \frac{b_{w}}{b_{f}}\left(\frac{k}{\lambda_{w}}+\frac{\lambda_{w}}{k}\right)^{2}+0.37794\left[10\left(\frac{\lambda_{w} b_{w}}{k b_{f}}\right)^{2}\right.\right. \\
& \left.\left.+6.766+2\left(\frac{k b_{f}}{\lambda_{w} b_{w}}\right)^{2}\right]\right\} \\
& m_{12}=t\left(1+0.37794 \frac{b_{f}}{b_{w}}\right)
\end{aligned}
$$

以上より，本論文で提案する溝形断面部材の局部座屈耐力評価式は 式(19)により表現される。なお，リップなしの溝形断面部材を検討 する場合は， $c=0$ として計算すればよい.

${ }_{p r o} N_{c r . l}=\min \left(\sigma_{c r . l}\right) A_{g}$

\section{2. 溝形断面部材の形状と弾性局部座屈耐力の関係性}

本節では 2.1 節で提案した弾性局部座屈耐力式 (19)を用いて，溝 形断面部材の断面形状々弾性局部座屈耐力，座屈性状の関係性を明 らかにする。断面形状と座屈性状の関係性の検討範囲については, Fig. 3 に示す国内で製造される薄板軽量形鋼 ${ }^{16)}$ （Fig. 3 中の LG）と軽 量形鋼 $^{21)}$ (Fig. 3 中の LW）の形状比率から, ウェブせいに対するフ ランジ幅，リップ幅の比率の上限值をそれぞれ $b_{f} / b_{w} \leq 1.00, c / b_{w} \leq 0.25$

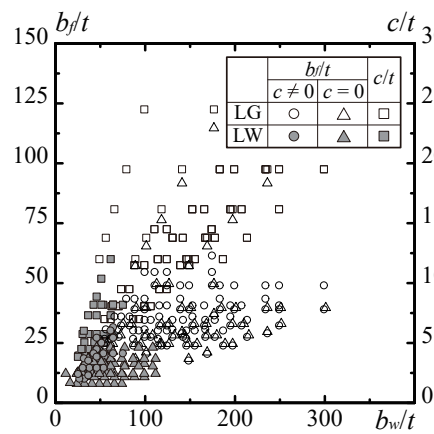

(a) Width-to-thickness ratio

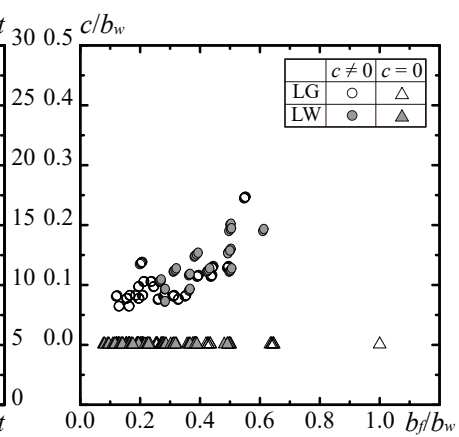

(b) Aspect ratio
Fig. 3 Manufacturing range for channel and lipped channel member 
と設定した。これら形状には局部座屈が 1 次モードとならない場合 も含まれるが，本論文では局部座屈により決定される座屈耐力のみ を抽出し, 他の座屈性状の座屈耐力との大小関係は本論文内では議 論しない.

Fig. 4 に提案式 (19)により求めた弾性局部座屈耐力とウェブ辺長比 $\lambda_{w}$ の関係を示す。縦軸は提案式 (19) から求めた弾性局部座屈耐力を Table 1 に示すウェブ座屈係数 $k_{w}$ に変換した結果である．提案式 (19) に基づき座屈半波数 $k$ ごとに弾性局部座屈耐力を計算すると Fig. 4 中 の破線が得られる．太実線はあるウェブ辺長比 $\lambda_{w}$ においての破線の 最小值を結ぶことで描いている。すすおち, 太実線は局部座屈の 1 次モードを与える固有值を意味し, 提案式 (19) は局部座屈モードの 1 次固有值を与えるものである. 本節での検討では $b_{w}=150 \mathrm{~mm}$ と固 定した数值計算を行い, 提案式 (19) により求められる太実線のみ抽 出し, 弾性局部座屈耐力をウェブ座屈係数 $k_{w}$ に変換した上で, 溝形 断面部材の断面形状と座屈性状の関係性を考察する.

リップ幅比率 $c / b_{w}$ が弾性局部座屈耐力に及ぼす影響を Fig. 5 に示 す。ここではウェブ幅厚比 $b_{w} / t$ を 100 と固定し, Fig. 5(a)では $b_{f} / b_{w}=$ 0.50, Fig. 5(b) では $b_{f} / b_{w}=1.00$ とした. 図中の点線は圧縮力を受ける 四辺単純支持の板要素の座屈係数 $k_{w}=4.0$ と四辺固定支持の板要素の 座屈係数 $k_{w}=6.98$ を示している ${ }^{15}$. Fig. 5(a), (b) を比較すると, フラ ンジ幅比率 $b_{f} f b_{w}=1.00$ の方がリップ幅比率の影響を受け, 耐力が上 昇している。 これはフランジ幅比率が大きくなると相対的にフラン ジの局部座屈が生じやすくなるが, リップ幅比率の増加により，フ ランジの座屈変形を拘束するため, フランジ幅比率の大きい範囲で リップの拘束効果が現れやすくなることが要因と考えられる。しか し，フランジ幅比率が大きい場合でも，リップ幅比率が局部座屈耐 力に与える影響は大きくない.

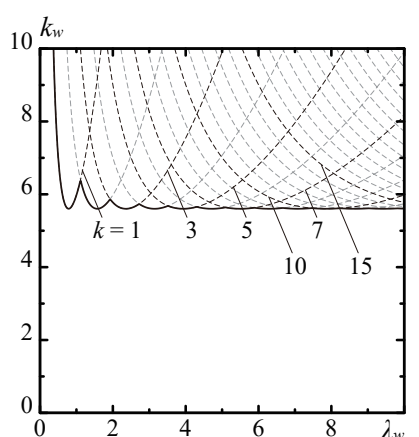

(a) C150_100_0.50_0.10

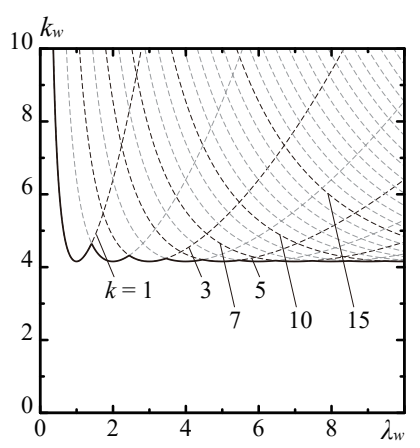

(b) C150_100_1.00_0.10
Fig. 4 Variation of buckling coef. $k_{w}$ with respect to $\lambda_{w}$

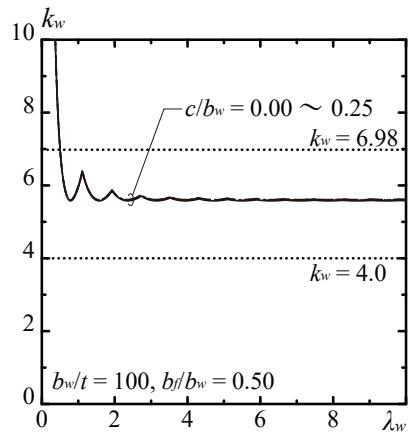

(a) C150_100_0.50_variable

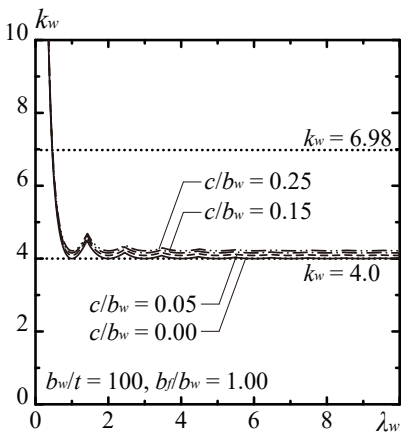

(b) C150_100_1.00_variable
Fig. 5 Variation of buckling coef. $k_{w}$ with respect to $c / b_{w}$
次にウェブに対するフランジ幅比率 $b_{f} / b_{w}$ が弾性局部座屈耐力に及 ぼす影響を Fig. 6 により考察する。ここではウェブ幅厚比 $b_{w} / t$ を 100 と固定し, Fig. 6(a) では $c / b_{w}=0.00$, Fig. 6(b)では $c / b_{w}=0.25$ とした.リッ プの有無に関わらず，フランジ幅比率の低下に伴いウェブ座屈係数 が増加する。こ机は断面内の板厚が均一であるため, フランジ幅比 率が低下すると相対的にフランジの幅厚比が低下し，フランジの局 部座屈が抑制され，フランジによるウェブへの拘束効果を高めるた めである. 同一の座屈半波数で極小值を与えるウェブ辺長比を比較 すると, $b_{f} / b_{w}=1.00$ に比較し $b_{f} / b_{w}=0.25$ の方が短い座屈半波長となっ ている.すなわち, 座屈半波長による判断からもフランジ幅比率の 低下に伴い，ウェブの支持条件が四辺単純支持から四辺固定支持条 件に近づき，フランジによるウェブへの拘束効果を高めることが確 認できる。

最後にウェブ幅厚比 $b_{w} / t$ が弾性局部座屈耐力に及ぼす影響を Fig. 7 に示す。ここではフランジ幅比率 $b_{f} b_{w}$ を 1.00 と固定し, Fig. 7(a)で は $c / b_{w}=0.00$, Fig. 7(b) では $c / b_{w}=0.25$ とした. Fig. 7 に示すようにウェ ブ幅厚比が変化しても, ウェブ座屈係数は変化しない，これは断面 内の板厚が均一であるため, ウェブ幅厚比が変化しても式 (8) のひず みエネルギー増分 $\Delta U_{1}, \Delta U_{2}, \Delta U_{3}$, 式 (9) の外力による仕事増分 $\Delta T_{1}$, $\Delta T_{2}, \Delta T_{3}$ が一定の比率で変化することが要因である.

Fig. 4 から Fig. 7 に示すように, ウェブ辺長比 $\lambda_{w}$ が小さい範囲では ウェブ辺長比の増加によりウェブ座屈係数が変動するものの, 各座 屈半波数 $k$ 毎に得られる最小ウェブ座屈係数は同值であり, $\lambda_{w}=10$ 程度でこの最小值へと収束していく.

本節で得られたウェブ座屈係数 $k_{w}$ の変化を Fig. 8 にまとめて表記 する.ここでは局部座屈耐力が十分に収束した值を抽出するためウエ ブ辺長比を $\lambda_{w}=20$ として計算した。縦横軸をそれぞれリップ幅比率

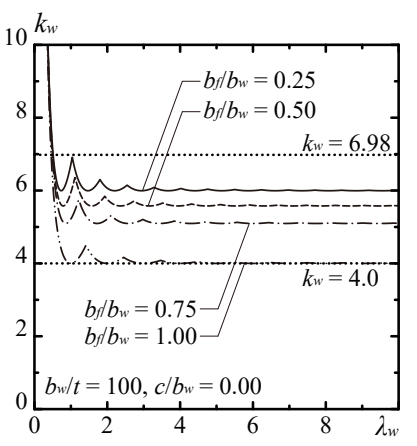

(a) C150_100_variable_0.00

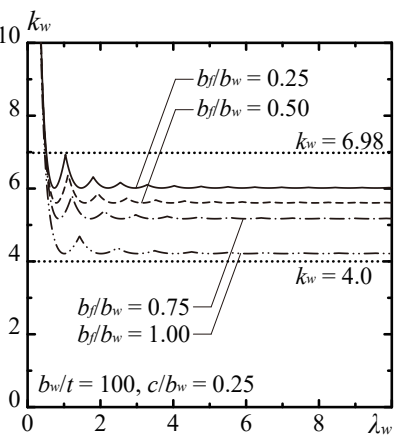

(b) C150_100_variable_0.25
Fig. 6 Variation of buckling coef. $k_{w}$ with respect to $b_{f} / b_{w}$

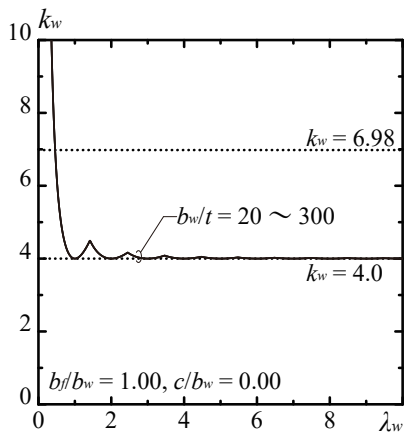

(a) C150_variable_1.00_0.00

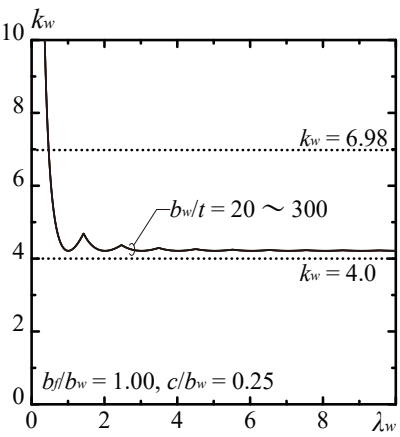

(b) C150_variable_1.00_0.25
Fig. 7 Variation of buckling coef. $k_{w}$ with respect to $b_{w} / t$ 


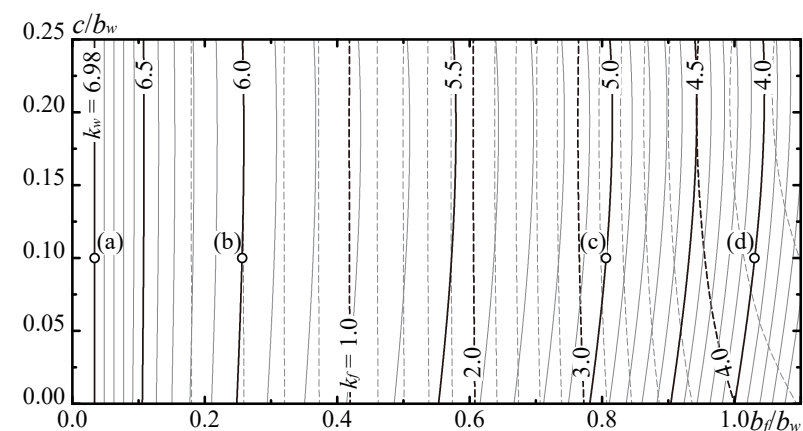

Fig. 8 Changing of buckling coef. $k_{w}, k_{f}$ with respect to the shape

$c / b_{w} ，$ フランジ幅比率 $b_{f} / b_{w}$ として，ウェブ座屈係数の変化を実線の 等高線により示している. また, ウェブ座屈係数から変換したフラ ンジ座屈係数 $k_{f}$ の変化も破線の等高線により併せて示している. Fig. 8 からも断面形状の変数の中でウェブ座屈係数に及ぼす影響の大部分 がフランジ幅比率 $b_{f} f b_{w}$ であり, リップ幅比率 $c / b_{w}$ の影響は小さいこ とがわかる．ここで，溝形断面部材の断面形状に応じ変化する座屈 係数と局部座屈モードの対応を Fig. 9 により確認する. Fig. 9 は Fig. 8 中に示す (a), (b), (c), (d) の位置に対応する 2 半波長分の座屈波形で ある. ウェブ座屈係数が 6.98 となる (a) ではウェブのみに座屈波形が 生じており，ウェブ支持辺に回転が生じていない，座屈半波長 $l_{c r}$ も $0.68 b_{w}$ となっており, 板要素が固定支持条件で局部座屈する特徵が 現れている ${ }^{15)}$. ウェブ座屈係数が 4.0 となる (d) では，各板要素に座 屈波形が生じている，この時の座屈半波長 $l_{c r}$ は $1.00 b_{w}$ であり，板要 素が単純支持条件で局部座屈する特徵が現れている ${ }^{15)}$. フランジ幅 比率の増加に伴いウェブ座屈係数が 6.98 から 4.0 へと低下し, この 時の座屈モードは (b), (c) のように徐々に固定支持条件の座屈モード から単純支持条件の座屈モードへと変化していく.

Fig. 8 の破線で示されるフランジ座屈係数 $k_{f}$ の変化を確認する. 本 論文は一様圧縮応力・一様板厚条件下で, フランジ幅はウェブせい より小さい範囲を対象としているため, フランジ幅比率変化に伴う フランジ座屈係数の増減はウェブ座屈係数と逆行し，フランジ幅比 率の増加に伴いフランジ座屈係数が増加する. Fig. 8 に示すように Fig. 3 の現実的な溝形断面部材の形状では, 溝形断面部材に局部座屈 が発生した場合でもフランジ座屈係数はほとんど 4.0 以下となる．現 行の薄板軽量形鋼造建築物設計の手引き ${ }^{16)}$ では溝形断面部材でゆが み座屈の発生を抑制し, 局部座屈を発生させるための条件として, フランジ座屈係数が 4.0 となるための必要リップ幅を規定している. フランジ板要素とリップ板要素からなる力学モデルにおいて, リッ プ幅が小さい場合ではフランジとリップの接合線が移動し，ゆがみ 座屈の座屈性状が発現するが，リップ幅を増大させることでゆがみ 座屈から局部座屈へと座屈波形を変化させることができる，したがう て，フランジ板要素とリップ板要素からなる力学モデルにおいて， フランジ座屈係数が 4.0 となるための必要リップ幅の規定は正しい. 一方で, 溝形断面部材はウェブ・フランジ・リップにより構成され, 部材に局部座屈が発生した場合であっても, フランジ座屈係数が 4.0 となる範囲は Fig. 8 に示すように溝形断面部材の断面形状が正方形に 近い限定的な範囲に限られるため, 部材全体で考えると必要りップ 幅の規定は適切でない，前述のように必要リップ幅規定はゆがみ座 屈発生の抑制であると理解することができるため, ゆがみ座屈耐力 と本論文で導出した局部座屈耐力を比較し, ゆがみ座屈耐力が局部

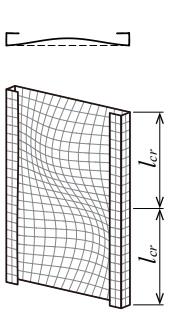

$l_{c r}=0.68 b_{w}$

(a) $k_{w}=6.98$

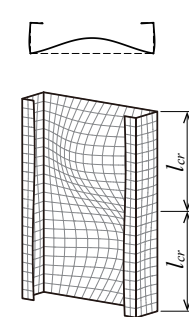

$l_{c r}=0.72 b_{w}$

(b) $k_{w}=6.0$
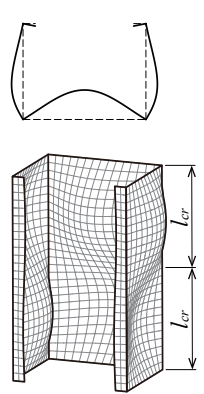

$l_{c r}=0.86 b_{w}$

(c) $k_{w}=5.0$
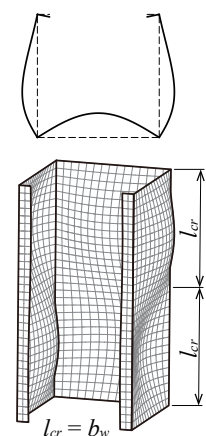

(d) $k_{w}=4.0$
Fig. 9 Local buckling modes shown in Fig. $8\left(c / b_{w}=0.10\right)$

座屈耐力を上回る範囲として必要リップ幅を規定すればよい. なお， フランジ幅に対するリップ幅の比率 $c / b_{f}$ の影響は Fig. 8 に示す結果に 内包されている，例えば，ウェブせいとフランジ幅を一定としてリッ プ幅を変化させ, 比率 $c / b_{f}$ を変化させた場合は Fig. 8 の縦軸方向の, ウェブせいとリップ幅を一定としてフランジ幅を変化させ，比率 $c / b_{j}$ を変化させた場合は Fig. 8 の横軸方向の変化と同義となる.

冒頭で述べたように，本論文では局部座屈現象のみを対象として いる. したがって, 構成板要素の幅厚比とリップ幅比率が小さく, フランジ幅比率が大きいような一部範囲ではゆがみ座屈が発生する と考えられるが，本論文ではゆがみ座屈に関する議論は行わず，ゆ がみ座屈の座屈耐力と部材の形状との関係性は別報にて報告する。

\section{3. 溝形断面部材の弾性局部座屈耐力の近似評価}

2.1 節では材長に応じて変化する弾性局部座屈耐力を算定できる耐 力式を提案したが，ウェブ辺長比が 10 程度で一定の值に収束してい くことが確認されており，断面形状に応じ変化する弾性局部座屈耐 力の収束值によって部材の弾性局部座屈耐力を評価できれば安全側 の評価に繋がる．そこで本章では提案式 (19) を簡略化し，断面形状 に応じ変化する収束值の弾性局部座屈耐力の近似評価を行う． 2.2 節 から, 溝形断面部材の弾性局部座屈耐力はウェブ幅厚比 $b_{w} / t$ の影響 を受けず，フランジ幅比率 $b_{f} / b_{w}$ とリップ幅比率 $c / b_{w}$ により影響を受 けることが明らかとなっている。この検討結果を利用し，本論文で は溝形断面部材の弾性局部座屈耐力式 (19)を式 (20)により近似した.

$$
{ }_{\text {app }} k_{w}= \begin{cases}6\left(\frac{b_{f}}{b_{w}}\right)^{2}+\frac{c / b_{w}-6}{b_{w}} b_{f}+7 & \left(0.0<\frac{b_{f}}{b_{w}} \leq 0.4\right) \\ -4\left(\frac{b_{f}}{b_{w}}\right)^{2}+\frac{c / b_{w}+3}{b_{w}} b_{f}+5 & \left(0.4<\frac{b_{f}}{b_{w}} \leq 1.0\right)\end{cases}
$$

近似式 (20) はウェブ座屈係数の表記であるが, 溝形断面部材の局部 座屈耐力を近似しているため, Table 1 に従い座屈応力度に変換し, 全断面積を乗じることで直接的に溝形断面部材の局部座屈耐力を算 出することが可能であり, 従来のような他の板要素との座屈耐力の 比較は必要としない.ここで, 近似式 (20) と圧縮力を受ける板要素 の座屈係数との対応および提案式 (19) との対応を Fig. 10 に示す. 実 線が近似式 (20) であり, ○の凡例が提案式 (19)により求めた数值解 析解である. 点線は圧縮力を受ける四辺単純支持の板要素の座屈係 数 $k_{w}=4.0$ と四辺固定支持の板要素の座屈係数 $k_{w}=6.98$ である. 破線 は小橋ら ${ }^{17)}$ - 19) が長方形断面部材の力学モデルに基づき導出した弾性 局部座屈耐力式をリップ付溝形断面部材に対して応用した弾性局部 座屈耐力式 (21)である. なお, 式 (21) の数式表現は本論文の記号に 


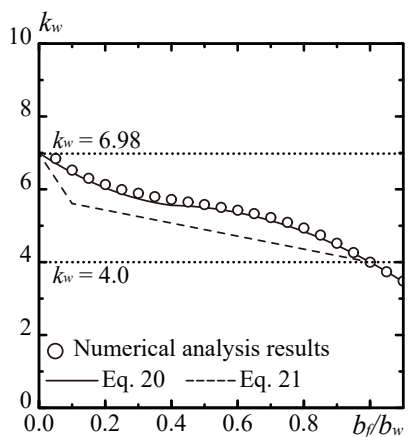

(a) $c / b_{w}=0.00$

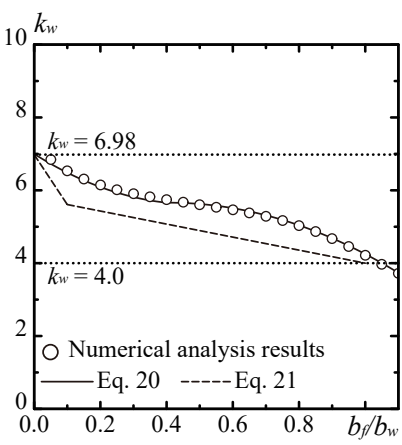

(b) $c / b_{w}=0.25$
Fig. 10 Web buckling coef. vs flange width ratio

合わせている。

$$
\begin{aligned}
& k_{w . K o b a s h i}=4 \gamma+6.98(1-\gamma)\left(0.0<\frac{b_{f}}{b_{w}} \leq 0.1\right) \\
& \gamma= \begin{cases}4.6 \frac{b_{f}}{b_{w}} & \left(0.1<\frac{b_{f}}{b_{w}} \leq 1.0\right) \\
0.4+0.6 \frac{b_{f}}{b_{w}} & \end{cases}
\end{aligned}
$$

従来設計法のようにウェブを四辺単純支持と見なした場合，その形状 に関わらず座屈係数は 4.0 となる。一方，Fig. 3 に示す現行の製造範 囲で多く製造されるような $0.10 \leq b_{f} f b_{w} \leq 0.60$ の範囲の座屈係数は 5.5 〜 6.5 であり, 本論文の近似式 (20) を使用した場合, 座屈耐力が 40 $\%$ ～ $60 \%$ ほど大きく算定される. また，式(21) は工学的な判断に基 づき長方形断面部材に対する安全側の耐力式を溝形断面部材に適用 させた耐力式となっているため，数值解析解を精緻には追従できな いが，弾性局部座屈耐力の変化傾向を捉えている，近似式 (20) は溝 形断面部材の更なる部材の高効率利用を図るべく, 小橋らが提案し た近似式 (21)の精度をさらに向上させたため, 式 (21)に比較し近似 式 (20) は座屈耐力を $10 \%$ 程度大きく算定する，ただし，リップ幅比 率の影響は小さいため, リップ幅の影響を無視し， $c=0$ と算定する ことで, より安全側の弾性局部座屈耐力を求めることも可能である.

最後に, 有限要素法による固有值解析結果と提案式 (19) と近似式 （20）を比較することで，その精度を検証する．ここでは汎用有限要 素法解析プログラム MSC. Marc 2019 により断面形状を解析パラメー タとした固有值解析を行った. Fig. 11 に解析モデルの概要を示す. 解析モデルは 4 節点シェル要素により構成されている. ウェブせい 方向は 20 等分割し，この要素サイズと同程度のサイズとなるように フランジ・リップの幅方向と材長方向の分割数を調整した．解析モ デルの両端部は剛体要素を介して断面の図心位置に接合されている. 図心位置 $\mathrm{A}$ はピン支持，図心位置 $\mathrm{B}$ は鉛直ローラー支持であり，両 点とも回転は拘束されている. ウェブとフランジの接合線の $z$ 軸方 向変位，フランジとリップの接合線の $y$ 軸方向変位は拘束し，局部 座屈以外の座屈モードが生じないように境界条件を設定した，外力 は鉛直荷重 $P$ を $\mathrm{B}$ 点に作用させ, 固有值が収斂するまで解析を行った。 材料特性はヤング係数 $E$ を $205000 \mathrm{~N} / \mathrm{mm}^{2}$ ， ポアソン比 $v$ を 0.3 とし て設定した，解析変数はウェブせい $b_{w}$ を 150 , ウェブ幅厚比 $b_{w} / t$ を 100 に固定し，フランジ幅比率 $b_{f} / b_{w}$ は $0.1 \sim 1.0$ までの範囲で, リッ プ幅比率 $c / b_{w}$ は $0.0 \sim 0.25$ までの範囲で変化させた.

ウェブ辺長比の変化を伴う弾性局部座屈耐力の評価を提案式 (19) に基づき行った結果を Fig. 12(a) に例示する。実破線は提案式 (19) か ら求めたウェブ座屈係数であり, ○とロの凡例が有限要素法による

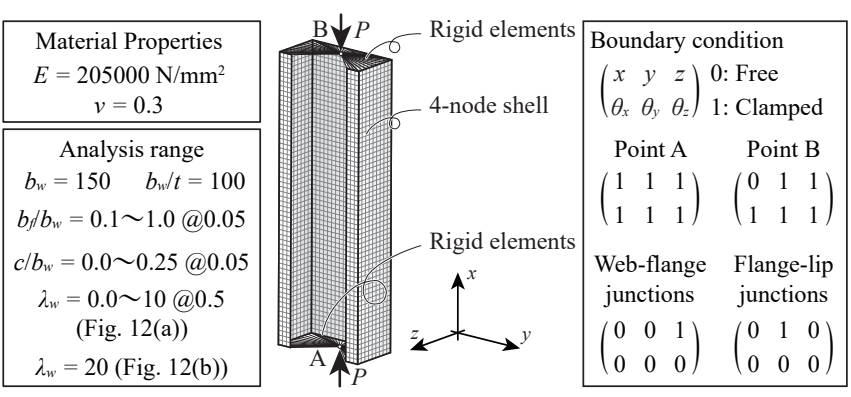

Fig. 11 Overview of FEA model
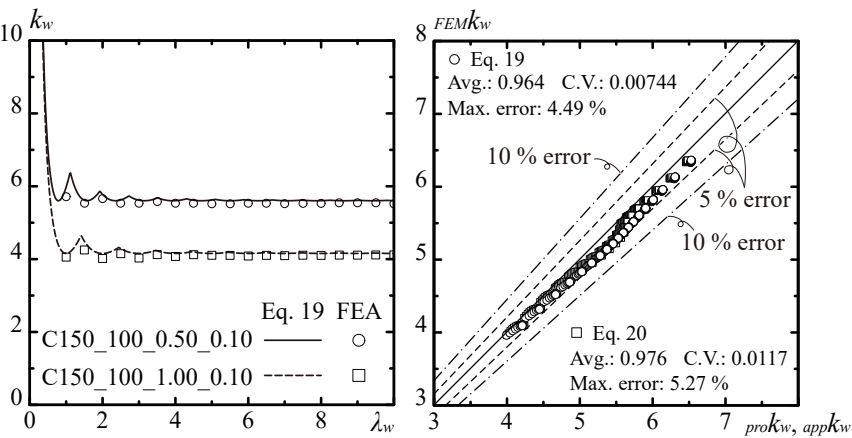

$\begin{array}{ll}\text { (a) Comparison with eq. } 19 & \text { (b) Comparison with eq. } 19 \text { or eq. } 20\end{array}$

Fig. 12 Comparisons between FEM results and eq. 19 or eq. 20

固有值解析結果である. 提案式(19) はウェブ辺長比の変化に伴うウェ ブ座屈係数の変化を追従し， ウェブ座屈係数が収束していく傾向と その収束值を正しく評価できている. Fig. 12(b) は Fig. 11 に示す解析 変数の範囲を対象に，ウェブ辺長比 $\lambda_{w}$ を局部座屈耐力が十分に収束 する $\lambda_{w}=20$ と設定し, 提案式 (19), 近似式 (20) と有限要素法固有值 解析の結果を比較した結果である。提案式 (19) に対する有限要素法 固有值解析結果の平均比率は 0.964 , 変動係数は 0.00744 , 最大誤差 は $4.49 \%$ となり, 提案式 (19) は溝形断面部材の局部座屈耐力を精度 良く評価できる，近似式 (20) は提案式 (19) に比較し簡便な数式表現 であるが, 近似式 (20) に対する有限要素法固有值解析結果の平均比 率は 0.976 , 変動係数は 0.0117 , 最大誤差は $5.27 \%$ となり, 工学的に 十分な精度で溝形断面部材の局部座屈耐力を評価可能である.

\section{4. 結}

本論文ではエネルギー法に基づき冷間成形溝形断面部材の諸変数 が弾性局部座屈耐力に及ぼす影響について考察した，以下に結論を まとめる。

1) 部材を構成する各板要素の相互作用による拘束効果を考慮すべ く, ウェブ・フランジ・リップの座屈波形を一連の変位関数によ り表現し，この変位関数を用いたエネルギー法により，溝形断面 部材の弾性局部座屈耐力式を提案し，その近似式を導出した。

2) フランジ幅比率 $b_{f} / b_{w}$ の違いによりリップ幅比率 $c / b_{w}$ が弾性局部 座屈耐力に与える影響が異なる。フランジ幅比率が大きくなると 相対的にフランジに局部座屈が生じやすくなるが, リップ幅比率 の増加により，フランジの局部座屈を拘束するため, フランジ幅 比率の大きい範囲でリップの拘束効果が現れやすい. しかし,リッ プ幅比率が局部座屈耐力に与える影響は小さい.

3) リップの有無に関わらず，断面内の板厚が均一であるためフラン ジ幅比率 $b_{f} / b_{w}$ が低下すると相対的にフランジの幅厚比が低下し， 
フランジの局部座屈が抑制され，弾性局部座屈耐力が増加する.

4) 現実的な溝形断面部材の形状では, 溝形断面部材に局部座屈が発

生した場合でもフランジ座屈係数はほとんど 4.0 以下となる. 現 行の薄板軽量形鋼造建築物設計の手引き ${ }^{16)}$ では溝形断面部材で ゆがみ座屈の発生を抑制し, 局部座屈を発生させるための条件と して, フランジ座屈係数が 4.0 となるための必要リップ幅を規定 しているが，板厚が断面内で一定となる冷間成形溝形断面部材の 製造範囲内でフランジ座屈係数が 4.0 となる範囲は極めて限定的 であるため, 必要リップ幅の設定根拠として適切でない.

5) 提案式 (19)により求められる弾性局部座屈耐力に対する有限要 素法弾性固有值解析結果の平均值は 0.967 , 変動係数は 0.00744 , 最大誤差は $4.49 \%$ であり, 提案式 (19)により溝形断面部材の弾 性局部座屈耐力を精度良く得られる. 提案式 (19)を簡便な表記 とした近似式 (20)によっても, 平均值が 0.976 , 変動係数は 0.0117 , 最大誤差は $5.27 \%$ 程度で弾性局部座屈耐力を評価可能である.

\section{参考文献}

1) K. Mitsui, A. Watanabe, T. Kobashi, K. Ikarashi: EFFECT OF GEOMETRICAL IMPERFECTIONN ON ANALYTICAL BUCKLING STRENGTH OF COLDFORMED LIPPED CHANNEL STEEL MEMBER UNDER COMPRESSION, Journal of Structural and Construction Engineering (Transactions of AIJ), Vol. 86, No. 779, pp. 157 - 167, 2021.1 (In Japanese)

2) American Iron and Steel Institute (AISI): North American Specification for the Design of Cold-Formed Steel Structural Members, 2016

3) CEN Brussels : EN 1993-1-1. Eurocode 3 - design of steel structures. Part 1-1, General rules and rules for buildings, 2005. 5

4) Australian/New Zealand Standard: Cold-formed Steel Structure, Standards Australia/Standards New Zealand, 1996

5) S. C. W. Lau, G. J. Hancock: Distortional Buckling Formulas for Channel Columns, Journal of Structural Engineering, Vol. 113 (5), pp. 1063 - 1078, 1987.5

6) G. J. Hancock: Design for Distortional Buckling of Flexural Members, Thin-Walled Structures, Vol. 27 (1), pp. 3 - 12, 1997. 1

7) G. J. Hancock, C. A. Rogers, R. M. Schuster: Comparison of the Distortional Buckling Method for Flexural Members with Tests, Proceeding $13^{\text {th }}$ International Specialty Conference on Cold-Formed Steel Structures, pp. 125 - 138, 1996. 10

8) G. J. Hancock, Young B. Kwon, E. Stefan Bernard: Strength Design Curves for Thin-Walled Sections Undergoing Distortional Buckling, Journal of Steel Research, Vol. 31 (2-3), pp. 169 - 186, 1994.3
9) Y. B. Kwon, G. J. Hancock: Strength tests of cold-formed channel sectiions undergoing local and distortional buckling, Journal of Structural Engineering, Vol. 117 (2), pp. 1786 - 1803, 1992

10) B. W. Schafer, T. Peköz: Laterally Braced Cold-Formed Steel Flexural Members with Edge Stiffened Flanges, Journal of Structural Engineering, Vol. 125 (2), pp. 118 - 127, 1999. 2

11) B. W. Schafer: Local, Distortional, and Euler Buckling of Thin-Walled Columns, Journal of Structural Engineering, Vol. 128, No. 3, pp. 289 - 299, 2002. 3

12) B. W. Schafer: Distortional buckling of cold-formed steel columns: Finel report Sponsored by the American Iron and Steel Institute, 2000. 8

13) B. W. Schafer, T. Peköz: Direct Strength Prediction of Cold-Formed Steel Members Using Numerical Elastic Buckling Solutions, Proceeding $14^{\text {th }}$ International Specialty Conference on Cold-Formed Steel Structures, 1998. 10

14) F. Bleich: Buckling Strength of Metal Structures, McGraw-Hill Book Co. Inc., 1952

15) AIJ : AIJ Recommendations for Stability Design of Steel Structures, 2018. 2 (In Japanese)

日本建築学会 : 鋼構造座屈設計指針, 2018.2

16) Guide for Designing Cold-formed Steel Structures 2nd Edition, Gihodo Shuppan Co.,Ltd. , 2014 (in Japanese) 薄板軽量形鋼造建築物設計の手引き第 2 版, 技報堂出版, 2014

17) T. Kobashi, K. Ikarashi, N. Simizu: ELASTIC LOCAL BUCKLING STRENGTH AND MAXIMUM STRENGTH OF COLD FORMED STEEL MEMBERS WITH DIFFERENT PLATE WIDTH ON ADJACENT PLATE ELEMENTS, Journal of Structural and Construction Engineering (Transactions of AIJ), Vol. 83, No. 749, pp 1051 - 1061, 2018.7 (In Japanese)

18) T. Kobashi, K. Ikarashi, N. Simizu: ELASTIC LOCAL BUCKLING STRENGTH AND MAXIMUM STRENGTH OF RECTANGULAR SECTIONN MEMBERS WHICH WERE LOADED COMPRESSION AND BENDING, Journal of Structural and Construction Engineering (Transactions of AIJ), Vol. 84, No. 755, pp 97 - 107, 2019. 1 (In Japanese)

19) T. Kobashi: DESIGN EQUATIONS FORELASTIC LOCAL BUCKLING STRENGTH OF LIPPED-C CHANNEL MEMBERS, $12^{\text {th }}$ Pacific Structural Steel Conference, p. 3-4-1, 2019. 11

20) K. Mitsui, R. Kuwada: COUPLED LOCAL BUCKLING STRENGTH OF H-SHAPED MEMBERS UNDER COMPRESSION, Journal of Structural and Construction Engineering (Transactions of AIJ), Vol. 86, No. 782, pp. 619 - 629, 2021. 4 (In Japanese)

21) Japanese Industrial Standards Committee: Light gauge steel sections for general structure, JIS G 3350, 2017 (In Japanese)

日本工業標準調査会 : 一般構造用軽量形鋼, JIS G 3350, 2017 


\title{
BUCKLING STRENGTH AND BEHAVIOR OF ELASTIC LOCAL BUCKLING FOR COLD-FORMED CHANNEL MEMBER UNDER COMPRESSION
}

\author{
Kazuya MITSUI ${ }^{* 1}$ and Kikuo IKARASHI*2 \\ *1 Assist. Prof., Dept. of Arch. and Build. Eng., Tokyo Institute of Technology, Dr.Eng. \\ ${ }^{*} 2$ Prof., Dept. of Arch. and Build. Eng., Tokyo Institute of Technology, Dr.Eng.
}

Singly-symmetric open sections in pure compression reveals two fundamental buckling modes: distortional and local, except for overall buckling such as bending buckling. Though these buckling modes reveal independently or in combination in channel members, this paper focuses on only independent local buckling. Traditionally, local buckling strength is calculated as a simply supported plate or fixed supported plate because its methodology is easy and plain. However, when such a simple buckling strength calculation method is applied to a member whose purpose is to thin the member and make advanced use, such as light gauge steel member, the local buckling strength must be calculated precisely. There is a concern that the advantages of these members will be lost. Therefore, in this paper, the buckling displacements of the web/flange/lip are expressed by a series of displacement functions. The elastic local buckling evaluation formula, which considers the element interactions, is proposed via the energy method. Also, the relationship between the cross-sectional shape of the channel member and the buckling behavior is clarified. Finally, comparisons between the proposed and conventional formulae are described.

From this research, the following are found.

1) To consider the restraint effect due to the element interaction of each plate that constitutes the member, the buckling waveform of the web/ flange/lip is expressed by a series of displacement functions. Using this displacement function, the elastic local buckling strength formula for the channel member is proposed by the energy method.

2) The lip width ratio's effect on the elastic local buckling strength differs depending on the difference in the flange width ratio $b_{f} / b_{w}$. When the flange width ratio becomes large, local buckling is relatively likely to occur in the flange; however, as the lip width ratio $c / b_{w}$ increases, the flange's local buckling is restrained so that the lip restraining effect appears in a range where the flange width ratio is large. However, the effect of the lip width ratio on the local buckling resistance is not large.

3) Since the plate thickness in the cross-section is uniform regardless of the presence or absence of lips when the flange width ratio decreases, the flange's width-thickness ratio decreases relatively, and local buckling of the flange is suppressed. As a result, the elastic local buckling strength increases.

4) The flange coefficient is almost 4.0 or less in the channel member's realistic shape even when local buckling occurs in the channel member. The current design manual for light gauge steel members stipulates the required lip width for the flange buckling coefficient to satisfy 4.0 to suppress distortion buckling and cause local buckling. However, since the range in which the flange buckling coefficient satisfies 4.0 within the channel member's manufacturing range is limited, it is not appropriate as a basis for setting the required lip width.

5) The average value of the finite element elastic eigenvalue analysis results against the elastic local buckling strength obtained from the proposed formula (19) is 0.967 , the standard deviation is 0.00744 , and the maximum error is $4.49 \%$. The approximate formula (20) can also obtain reasonably calculated results, which is a simple notation of the proposed formula (19). 